\title{
Morphine-induced stimulation of pituitary-adrenocortical activity is mediated by activation of nitric oxide in the early stages of postnatal life in the rat
}

\author{
J Lesage, F Bernet, V Montel and J P Dupouy \\ Laboratoire de Neuroendocrinologie du Développement, UPRES-EA 2701, Université de Lille 1, Bât. SN4, 59655 Villeneuve d'Ascq, France \\ (Correspondence should be addressed to J Lesage; Email: jlesage@univ-lille1.fr)
}

\begin{abstract}
Objective: The first aim of the present study was to determine if morphine, a prototypic $\mu$-opioid agonist drug, affects pituitary-adrenocortical activity in developing rat pups (first and second weeks of postnatal life). The second aim of this study was to explore, in vivo, if nitric oxide (NO) could be involved in the neurohormonal response to morphine in the early stages of postnatal life.

Methods: Plasma ACTH and corticosterone concentrations were determined by RIA in rat pups $(n=5-14$ rats/experimental group) after they had been killed by decapitation. In a first experiment, 1-day and 1- and 2-week-old rats were treated s.c. with morphine $(20 \mathrm{mg} / \mathrm{kg})$ or with vehicle $(0.9 \%$ $\mathrm{NaCl}$ ) and killed 5-90 min later. In a second experiment, 2-week-old pups were pretreated s.c. with naltrexone (NAL; $0.4 \mathrm{mg} / \mathrm{kg}$ or $10 \mathrm{mg} / \mathrm{kg})$, and injected $1 \mathrm{~h}$ later with either morphine $(20 \mathrm{mg} / \mathrm{kg})$ or vehicle, and killed $30 \mathrm{~min}$ later. Some pups injected with only NAL were killed 60 or 90 min later. On the other hand, pups injected with NAL $(10 \mathrm{mg} / \mathrm{kg})$ or NAL and morphine were killed $30 \mathrm{~min}$ later. In a third experiment, 2-week-old pups were pretreated s.c. with $\mathrm{N}$ - $\omega$-nitro L arginine methylester (L-NAME; $30 \mathrm{mg} / \mathrm{kg}$ or $100 \mathrm{mg} / \mathrm{kg}$ ), and injected $1 \mathrm{~h}$ later with either morphine $(20 \mathrm{mg} / \mathrm{kg}$ ) or vehicle, and killed $30 \mathrm{~min}$ later. Moreover, some pups injected with L-NAME $(100 \mathrm{mg} / \mathrm{kg})$ or L-NAME with morphine were killed 30 min later. In a final experiment, pups were injected s.c. with either S-nitroso-N-acetylpenicillamine (SNAP; $5 \mathrm{mg} / \mathrm{kg}$ ) or vehicle, and killed 60 or 90 min later.

Results: Morphine administered to rat pups elicited marked rises in both ACTH and corticosterone secretion. Moreover, these responses increased with advancing postnatal age. In 2-week-old rat pups, NAL, a competitive antagonist at $\mu$-opioid receptors, administered alone increased both plasma ACTH and corticosterone concentrations 30 min later. L-NAME, a specific NO synthase inhibitor, did not affect plasma ACTH and corticosterone concentrations 30 min later when administered alone. NAL, when concomitantly administered with morphine, was unable to block morphine responses. In contrast, morphine responses were blocked by pretreatment (60 min before) with NAL or with L-NAME. Acute injection of SNAP increased both ACTH and corticosterone release. Conclusion: Our results suggest that opioids have controversial effects on pituitary-adrenocortical activity in the early postnatal period in the rat, and that endogenous NO is one of the major factors in the response of the pituitary-adrenocortical axis to morphine.
\end{abstract}

European Journal of Endocrinology $144441-451$

\section{Introduction}

In adult rats, acute administration of morphine has been reported to stimulate the hypothalamo-pituitaryadrenal (HPA) axis (1) but to inhibit the release of gonadotrophins (2). In rats, the HPA axis is already functional in fetuses in late gestation (3). We have previously reported that the exposure of pregnant rats to morphine induces both atrophy and hypoactivity of the adrenals for corticosterone release in newborns at birth and during the early postnatal period (4). As such effects of morphine on the HPA axis were not observed in newborns from adrenalectomized females (5), a direct action of this drug on the fetal brain when administered to the mother is unlikely. However, according to several studies, opiate drugs such as heroin or morphine can be transferred through the placenta from the pregnant female to the fetus (6).

Sexual differentiation of the brain, which occurs perinatally in several species, including the rat, can be affected by exposure of the developing nervous system to opiates (2). Three major opioid receptor subtypes, mu $(\mu)$ kappa $(\kappa)$ and delta $(\delta)$ have been pharmacologically characterized (7). The $\mu$-opioid receptor shows high affinity for morphine-like drugs as well as for dynorphin $A$ and for several endogenous opioid 

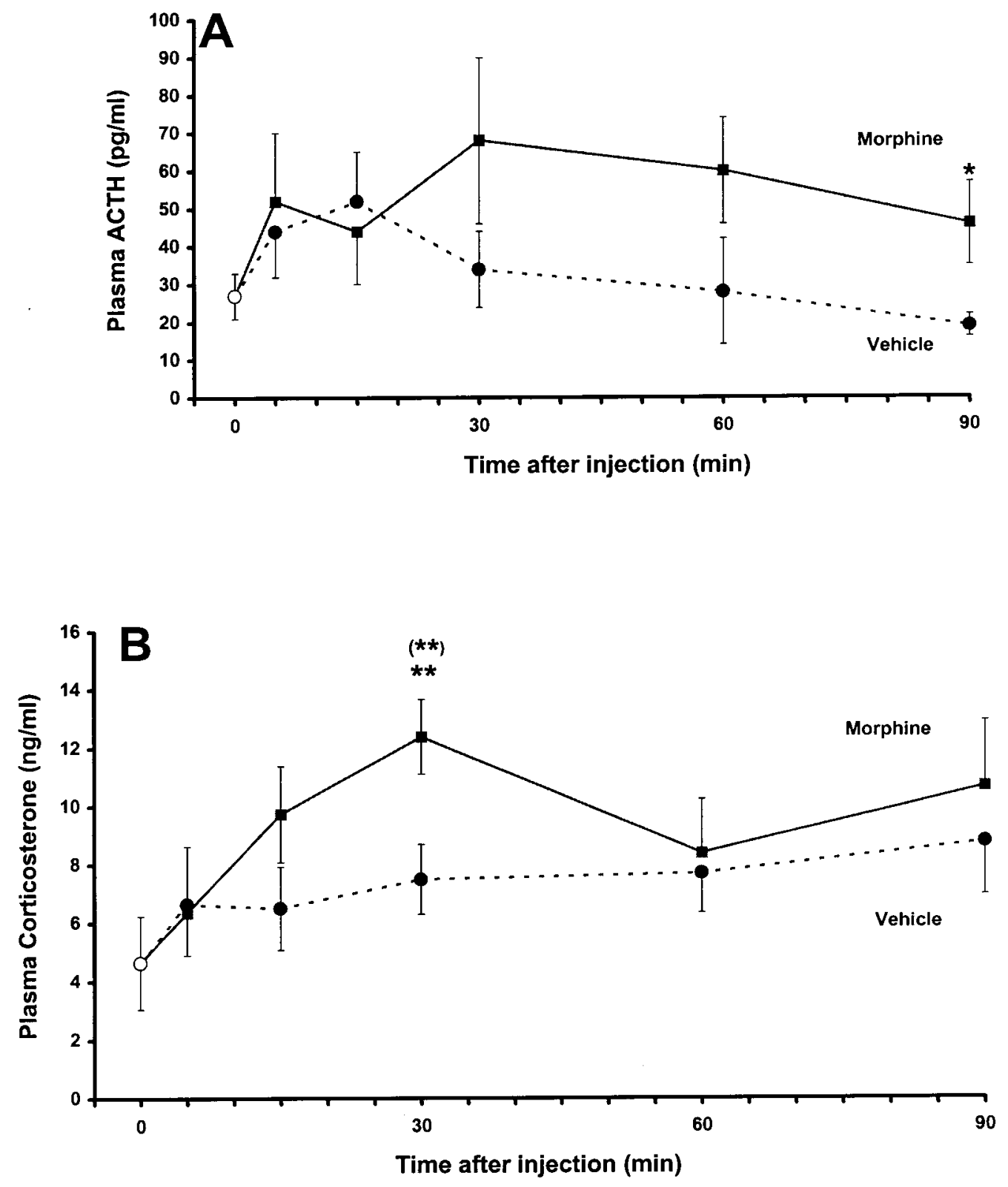

Figure 1 Plasma ACTH (A) and corticosterone $(B)$ concentrations in 1-day-old newborn rats $(\mathrm{J} 1)$ before $(\mathrm{O})$ and after morphine injection (20 mg/kg; morphine group, $\mathbf{\square})$ or $0.9 \% \mathrm{NaCl}$ injection (vehicle group, $\bullet$ ). Values are means \pm S.E.M. $(n=10-14)$. $\left({ }^{\star *}\right)$ $P<0.01$ vs time 0 min. ${ }^{\star} P<0.05,{ }^{\star}{ }^{*} P<0.01$ morphine vs vehicle group at the same time.

peptides, including mainly pro-opiomelanocortinderived $\beta$-endorphin.

Opioid receptors are first detectable within the rat central nervous system on embryonic day 14 (8). The distribution of $\mu$-opioid receptor mRNA in the rat brain increases between embryonic days 16 and 22 and continues to increase until postnatal day 7 to a level equivalent to the adult one (9). The coexistence of $\mu$ and $\kappa$ - but not $\delta$-opioid sites has been reported in the human fetal brain (10), and during early neonatal life in the brain of both rat (11) and mouse (12). The development of opiate receptors in the rat brain may be sex hormone dependent, as 6-day-old females display more opiate-binding sites than age-matched males (13).

As the effects of opioids on neuroendocrine functions during the postnatal period are poorly documented (14), the first aim of the present work was to investigate, in vivo, the consequence of acute morphine administration on hypophysial corticotrophin (ACTH) 

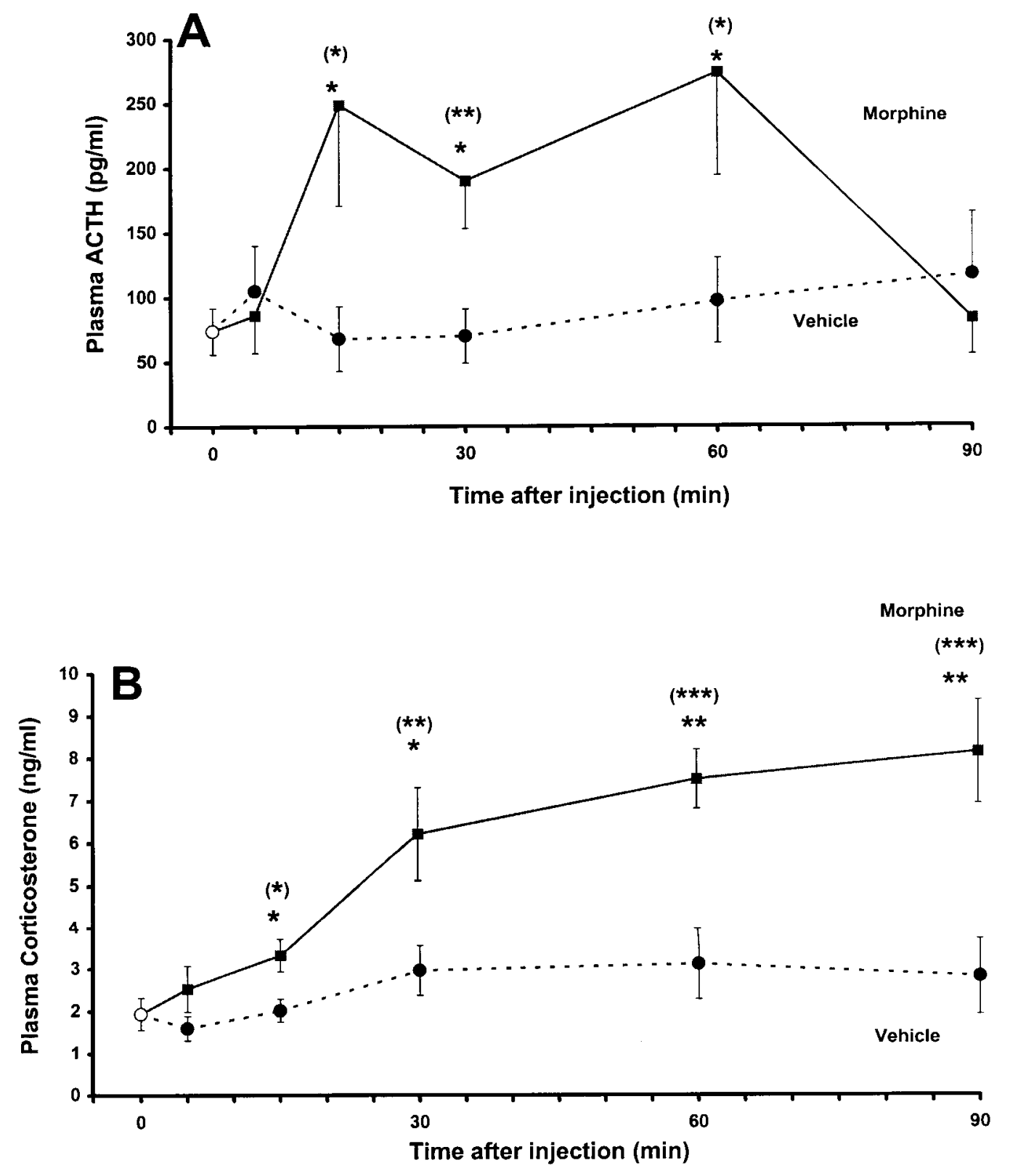

Figure 2 Plasma ACTH (A) and corticosterone (B) concentrations in 1-week-old newborn rats (W1) before $(O)$ and after morphine injection (20 mg/kg; morphine group, $\mathbf{\square})$ or $0.9 \% \mathrm{NaCl}$ injection (vehicle group, $\bullet$ ). Values are means \pm S.E.M. $(n=8-13)$. $\left(^{*}\right) P<0.05$, $\left.{ }^{\star \star \star}\right) P<0.01,\left({ }^{\star \star \star}\right) P<0.001$ vs time 0 min. ${ }^{\star} P<0.05,{ }^{\star \star} P<0.01$ morphine vs vehicle group at the same time.

release and corticosterone secretion in newborn rats at several stages of postnatal life (first and second week of life).

Experiments performed in vitro have suggested that morphine coupling to nitric oxide (NO) can stimulate both corticotrophin-releasing factor (CRF) and gonadotrophin-releasing hormone release from the median eminence of adult rats (15). The presence of NO synthase has been demonstated in several areas of the adult rat brain, including the hypothalamic paraventricular nucleus, and in a subpopulation of CRF-expressing neurones (16). Nevertheless, with respect to the role of endogenous NO, conflicting results have been reported, suggesting either stimulatory or inhibitory effects of NO on CRF release (17).

Thus, the second aim of this work was to test whether NO contributes to the release of ACTH and corticosterone in early postnatal life, and whether NO could mediate the endocrine effect of morphine in the newborn rat. 

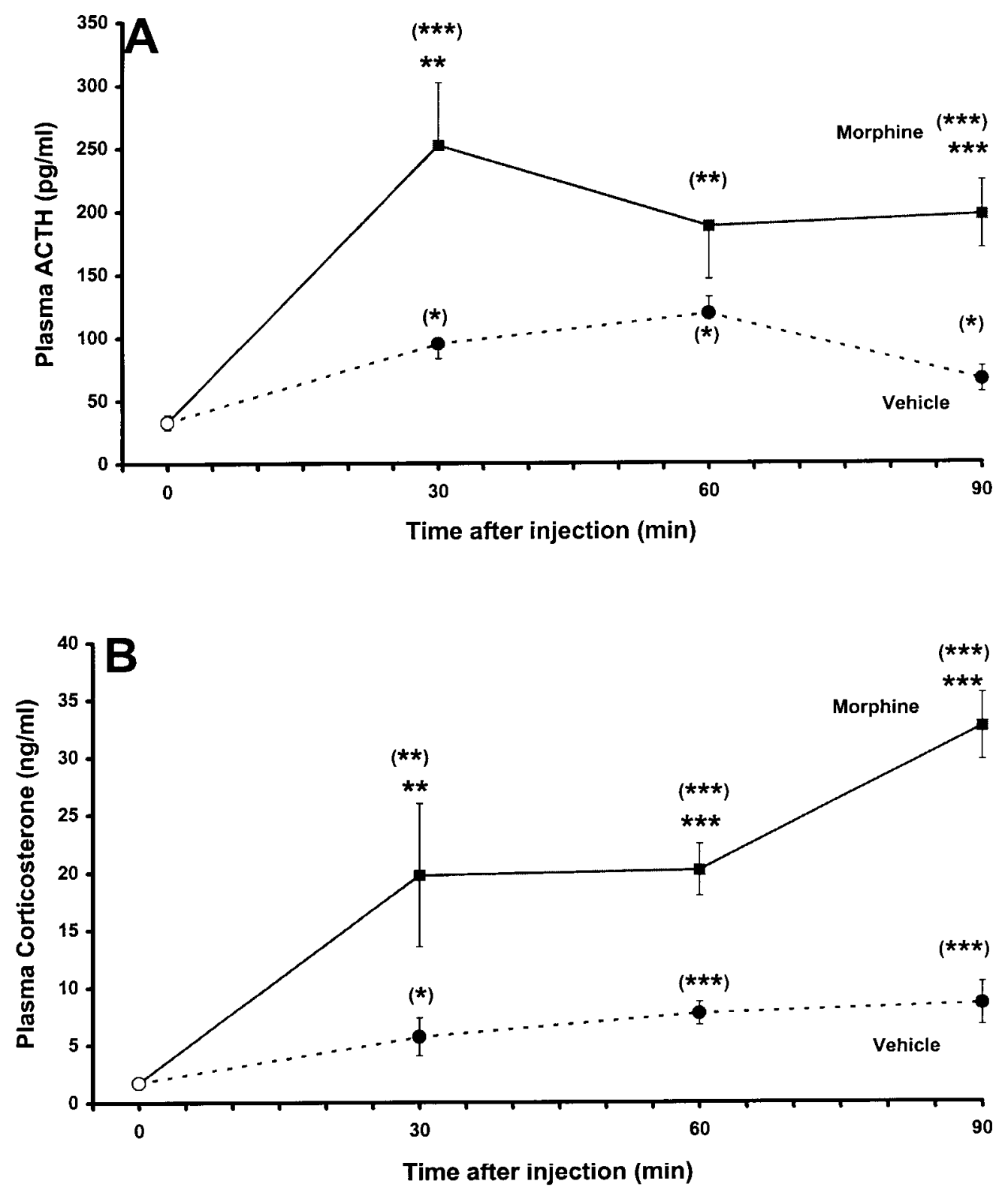

Figure 3 Plasma ACTH (A) and corticosterone (B) concentrations in 2-week-old newborn rats (W2) before (O) and after morphine injection (20 mg/kg; morphine group, $\mathbf{\square}$ ) or $0.9 \% \mathrm{NaCl}$ injection (vehicle group, $\bullet$ ). Values are means \pm S.E.M. $(n=7-12) .\left(^{\star}\right) P<0.05$ $\left.\left.{ }^{\star \star}\right) P<0.01,{ }^{\star \star \star}\right) P<0.001$ vs time 0 min. ${ }^{\star \star} P<0.01,{ }^{\star \star \star} P<0.001$ morphine vs vehicle group at the same time.

\section{Materials and methods}

\section{Animals}

Experiments were performed on Wistar rats bred in our laboratory. Animal accreditation by the French Ministry of the Agriculture (no. 04860) has been granted to our laboratory for experimentation with rats. Newborns spontaneously delivered vaginally were used 1 day (J1), 1 week (W1) or 2 weeks (W2) after birth.

\section{Treatment of the newborns}

In a first experiment, morphine sulphate (SanofiFrancopia, Paris, France) was dissolved in physiological saline $(0.9 \% \mathrm{NaCl})$ used as vehicle. Morphine is known as prototypic $\mu$-opioid receptor agonist, which is also an agonist at the $\kappa$-opioid receptor (18). On the basis of preliminary results showing that a single s.c. injection of $20 \mathrm{mg} / \mathrm{kg}$ morphine sulfate is more effective than a lower dose of $10 \mathrm{mg} / \mathrm{kg}$ at stimulating secretion of 

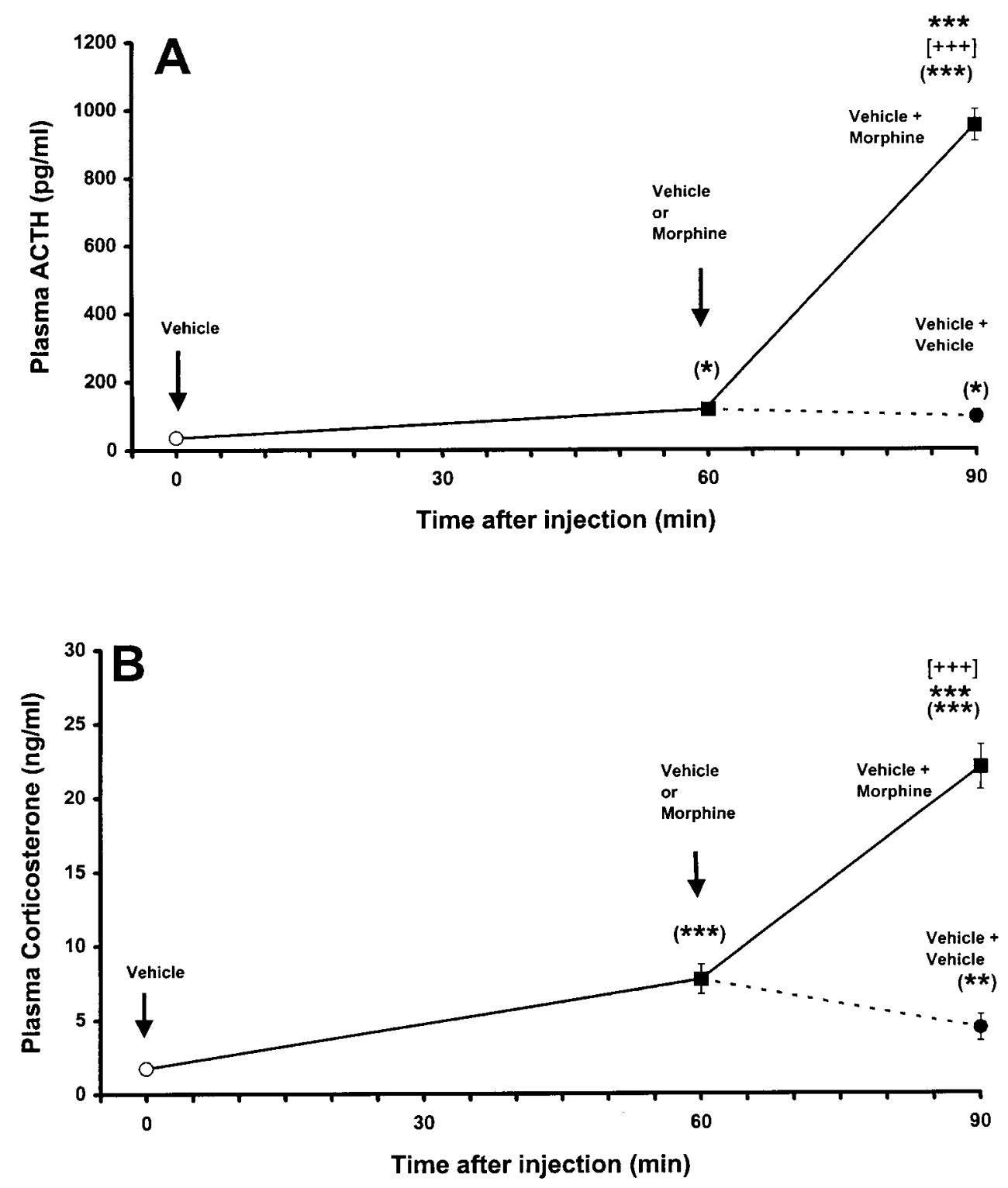

Figure 4 Plasma ACTH (A) and corticosterone (B) concentrations in 2-week-old newborn rats (W2) before (0 min) and $60 \mathrm{~min}$ following $0.9 \% \mathrm{NaCl}$ injection (vehicle) $(60 \mathrm{~min})$ at a time when the pups were subjected to a second injection of vehicle or morphine $(20 \mathrm{mg} / \mathrm{kg})$ before being killed $30 \mathrm{~min}$ later $(90 \mathrm{~min})$. Values are means \pm S.E.M. $(n=6) .\left({ }^{\star}\right) P<0.05,\left({ }^{\star \star}\right) P<0.01,\left({ }^{\star \star \star}\right) P<0.001 \mathrm{vs}$ time 0 min. $[+++] P<0.001$ vs time 60 min. ${ }^{* \star *} P<0.001$ vehicle + morphine vs vehicle + vehicle group at the same time.

ACTH and corticosterone in newborn rats, we selected the highest dose for this study. Newborns $(n=7-14$ rats/group) were treated with morphine given s.c. $(20 \mathrm{mg} / \mathrm{kg}$ in $0.025 \mathrm{ml}$ (J1 and W1) or $0.050 \mathrm{ml}$ saline (W2)) or the same volume of vehicle $(0.9 \% \mathrm{NaCl})$ for controls. Pups were killed 5, 15, 30, 60 or $90 \mathrm{~min}$ after the injection of the drug or the vehicle. Some littermate newborns ( $n=7$ rats), which were killed without previous treatment, were used as absolute controls. Morphine use accreditation by the French Ministry of Health (no. 9300196 S) has been granted to our laboratory for experimentation with rats. In a second experiment, 2-week-old newborns were pretreated with naltrexone hydrochloride (NAL; Sigma Chemical Co., St Louis, MO, USA), a competitive antagonist at $\mu-, \kappa-$ and $\delta$-opioid receptors $(0.4 \mathrm{mg} /$ $\mathrm{kg}$ or $10 \mathrm{mg} / \mathrm{kg}$ s.c. in $0.050 \mathrm{ml} 0.9 \% \mathrm{NaCl}$ used as vehicle). One hour later, newborns were injected with either morphine $(20 \mathrm{mg} / \mathrm{kg}$ s.c. in $0.050 \mathrm{ml}$ vehicle) or the same volume of vehicle ( $n=9-12$ rats/group), and killed $30 \mathrm{~min}$ later. Some pups ( $n=12$ rats) injected with only NAL were killed 60 or 90 min later. On the other hand, pups ( $n=8$ rats/group) injected with NAL $(10 \mathrm{mg} / \mathrm{kg})$ or NAL and morphine were killed $30 \mathrm{~min}$ 

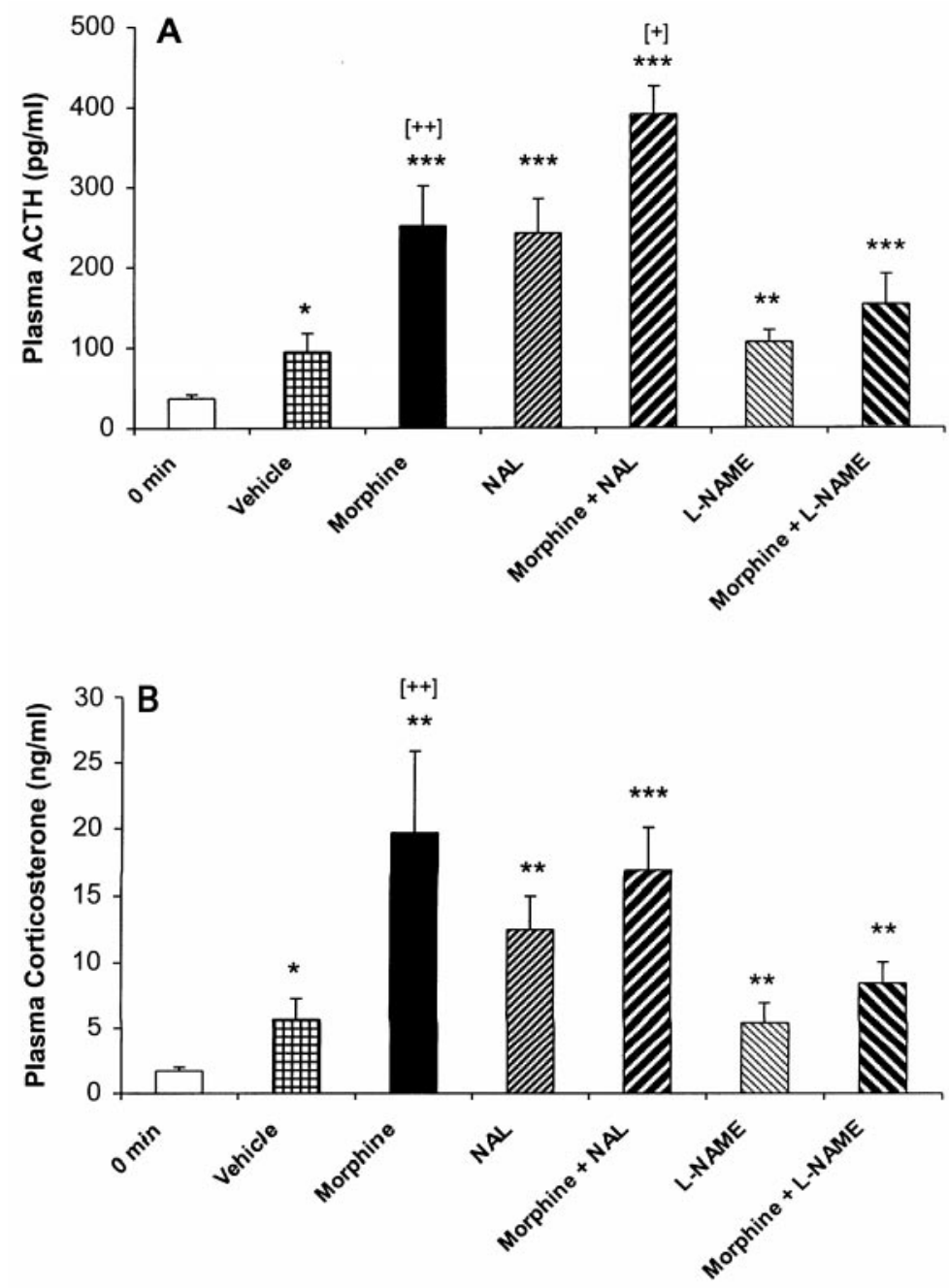

Figure 5 Plasma ACTH (A) and corticosterone (B) concentrations in 2-week-old newborn rats (W2) before $(0 \mathrm{~min}$ ) and $30 \mathrm{~min}$ after injection of $0.9 \%$ $\mathrm{NaCl}$, morphine $(20 \mathrm{mg} / \mathrm{kg})$, NAL $(10 \mathrm{mg} / \mathrm{kg})$, L-NAME (100 mg/kg), morphine and NAL, or morphine and L-NAME. Values are means \pm S.E.M. $(n=$ 5-12). ${ }^{\star} P<0.05,{ }^{\star \star} P<0.01,{ }^{\star \star \star} P<0.001$ vs time 0 min. $[+] P<0.05,[++] P<0.01$ vs respective controls (vehicle, NAL, L-NAME).

later. In a third experiment, 2-week-old newborns were pretreated with $\mathrm{N}-\omega$-nitro L arginine methyl-ester (LNAME) hydrochloride (Sigma), an NO synthase inhibitor $(30 \mathrm{mg} / \mathrm{kg}$ or $100 \mathrm{mg} / \mathrm{kg}$ s.c. in $0.050 \mathrm{ml} 0.9 \%$ $\mathrm{NaCl}$ used as vehicle). One hour later, newborns were injected with either morphine $(20 \mathrm{mg} / \mathrm{kg}$ s.c. in $0.05 \mathrm{ml}$ vehicle) or the same volume of vehicle $(n=$ 9-11 rats/group). The treated newborns were killed 30 min later. On the other hand, pups injected with LNAME $(100 \mathrm{mg} / \mathrm{kg})$ or L-NAME with morphine were killed 30 min later ( $n=7$ rats/group). In a final experiment, pups were injected with either S-nitrosoN-acetylpenicillamine (SNAP; Sigma), an NO donor $(5 \mathrm{mg} / \mathrm{kg}$ s.c. in $0.05 \mathrm{ml}$ vehicle) or the same volume of vehicle ( $n=10-13$ rats/group). Injected pups were killed 60 or 90 min later.

\section{Plasma collection}

Trunk blood samples were collected between 0900 and $1200 \mathrm{~h}$, after carotid section, in polyethylene tubes pre-rinsed with EDTA 5\% (w/v). The blood samples were centrifuged at $3500 \mathrm{~g}$ for $10 \mathrm{~min}$ at $4{ }^{\circ} \mathrm{C}$ and kept at $-30{ }^{\circ} \mathrm{C}$ until hormone assays. The sex of the pups was determined by examination of the genitals.

\section{Radioimmunoassays}

ACTH was measured in unextracted plasma by radioimmunoassay (RIA) using an ACTH kit (ACTHK-PR; Cis Bio International, Gif sur Yvette, France; sensitivity $10 \mathrm{pg} / \mathrm{ml}$ ). The characteristics of the antiserum have been reported previously (19). The intra- and interassay variations were, respectively, $4.3 \%(n=6)$ and $11.7 \%(n=9)$. Corticosterone assay in plasma was preceded by extraction in ethylacetate after delipidation in iso-octane. The percentage recovery of a known amount of this steroid was over $95 \%$. Corticosterone levels were determined by RIA using a highly specific corticosterone antiserum according to a previously detailed procedure (20) with a detection threshold of 

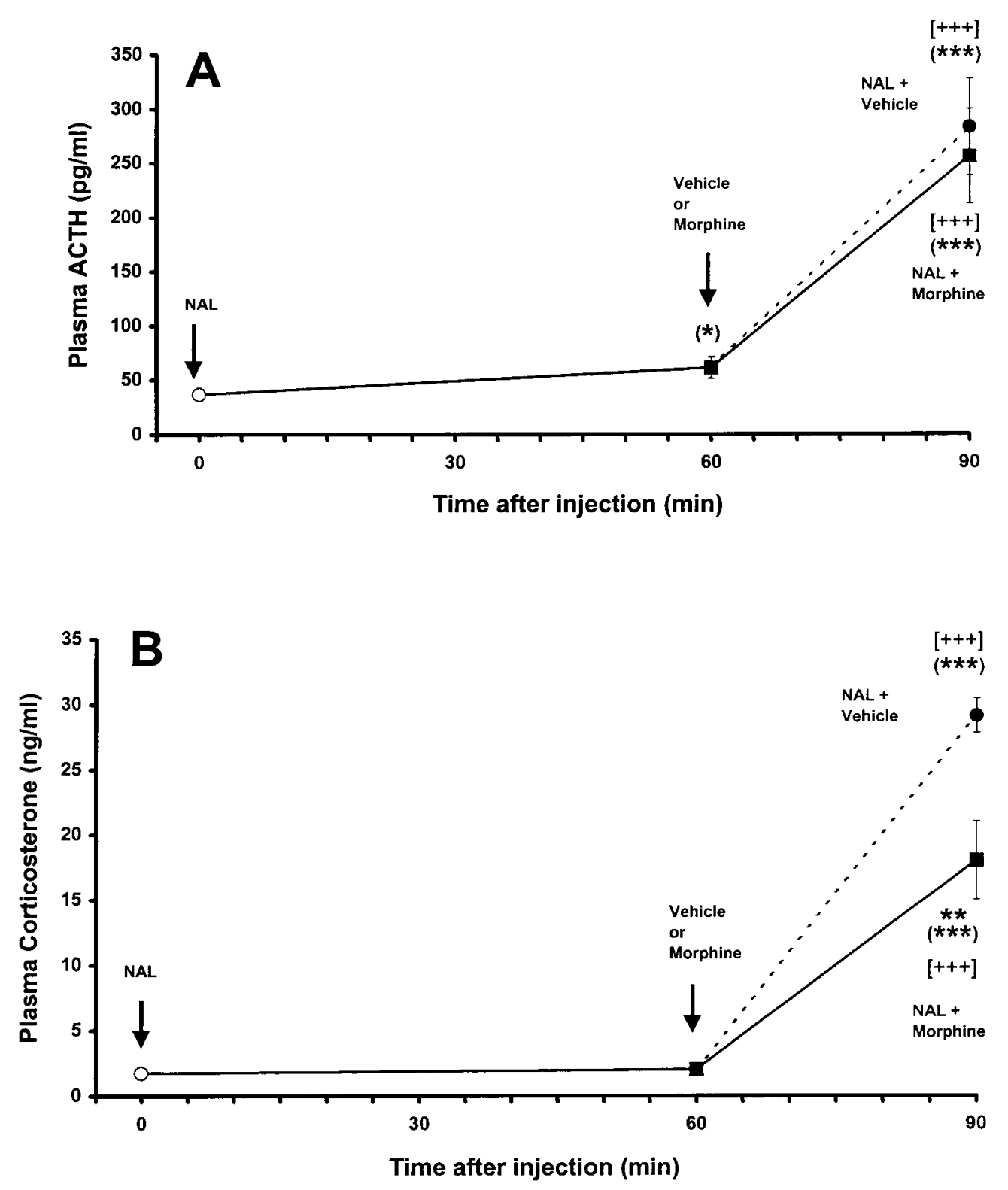

Figure 6 Plasma ACTH (A) and corticosterone (B) concentrations in 2-week-old newborn rats (W2) before (0 min) and $60 \mathrm{~min}$ following NAL $(10 \mathrm{mg} / \mathrm{kg})$ injection $(60 \mathrm{~min})$ at a time when the pups were subjected to a second injection of $0.9 \% \mathrm{NaCl}$ or morphine $(20 \mathrm{mg} / \mathrm{kg})$ before being killed $30 \mathrm{~min}$ later $(90 \mathrm{~min})$. Values are means \pm s.E.M. $\left.(n=9-12) .{ }^{\star}\right) P<0.05,\left({ }^{\star \star \star}\right) P<0.001 \mathrm{vs}$ time $0 \mathrm{~min}$. $[+++] P<0.001$ vs time 60 min. ${ }^{\star *} P<0.01$ morphine vs vehicle group at the same time.

$1 \mathrm{ng} / \mathrm{ml}$. The intra- and interassay variations were, Results respectively $2.4 \%(n=12)$ and $4.4 \%(n=4)$.

\section{Statistical analysis}

All data are presented as means \pm S.E.M. Multiple analysis of variance was performed followed by a Dunnet's test using a computer program. The Student's t-test was also used when appropriate. $P<0.05$ were considered statistically significant.

As no significant differences between sexes were observed for plasma concentrations of ACTH and corticosterone before and after treatment with either morphine or vehicle, values for male and female pups were pooled. Morphine given to 1-day-old newborns induced a slow and slight increase in the circulating concentration of ACTH which was significant only 90 min after drug injection (Fig. 1A). Morphine-treated pups showed significant increase in the plasma 

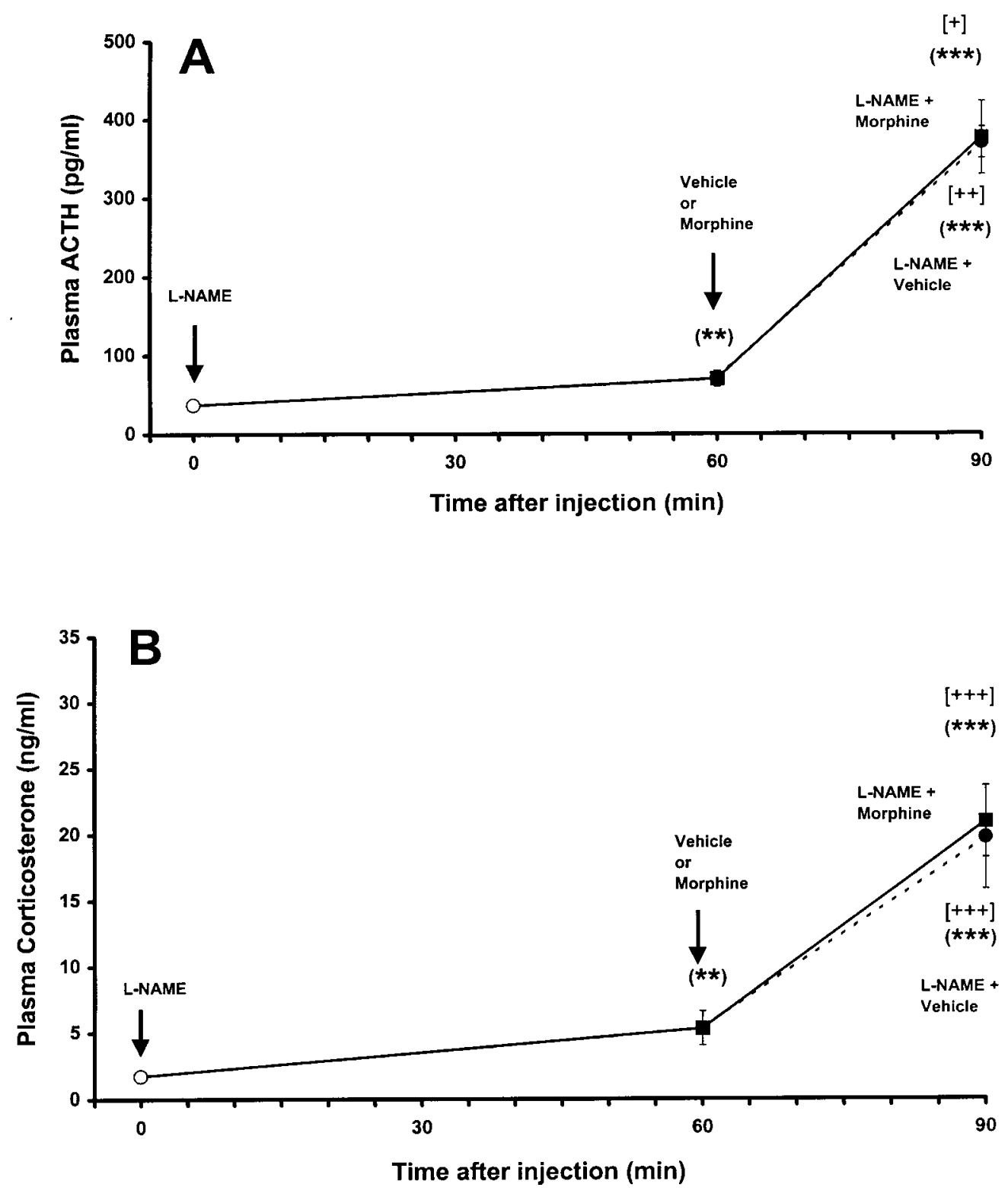

Figure 7 Plasma ACTH (A) and corticosterone (B) concentrations in 2-week-old newborn rats (W2) before $(0 \mathrm{~min})$ and $60 \mathrm{~min}$ following L-NAME $(100 \mathrm{mg} / \mathrm{kg})$ injection $(60 \mathrm{~min})$ at a time when the pups were subjected to a second injection of $0.9 \% \mathrm{NaCl}$ or morphine $(20 \mathrm{mg} / \mathrm{kg})$ before being killed $30 \mathrm{~min}$ later $(90 \mathrm{~min})$. Values are means \pm S.E.M. $(n=9-11) .\left({ }^{\star \star}\right) P<0.01,\left({ }^{\star \star \star}\right) P<0.001$ vs time 0 min. $[+] P<0.05,[++] P<0.01,[+++] P<0.001$ vs time $60 \mathrm{~min}$.

concentration of corticosterone at 30 min after injection (Fig. 1B). Morphine also activated the pituitaryadrenal axis in both 1-week-old (Fig. 2) and 2-week-old newborns (Fig. 3). However, morphine-induced ACTH and mainly corticosterone release were highest and more lasting in the latter pups (Fig. 3). Moreover, vehicle injection induced a slight but significant increase of both ACTH and corticosterone release at 30, 60 and 90 min in 2-week-old newborns (Fig. 3) but not in younger ones (Figs 1 and 2). Morphine-induced ACTH increase was more drastic in pups pretreated with vehicle (Fig. 4A) than in naive pups (Fig. 3A). NAL given alone to 2-week-old newborns at $0.4 \mathrm{mg} / \mathrm{kg}$ had no significant effect on the plasma concentration of ACTH and corticosterone $90 \mathrm{~min}$ after the injection (data not shown). In contrast, at $10 \mathrm{mg} / \mathrm{kg}$, NAL induced $30 \mathrm{~min}$ later (but not 60 or $90 \mathrm{~min}$ later) a significant rise in both plasma ACTH (Fig. 5A) and corticosterone (Fig. 5B) concentrations, but was unable to prevent morphine responses when this drug was administered concomitantly (Fig. 5). Vehicle injection given $60 \mathrm{~min}$ after an injection of NAL induced an 

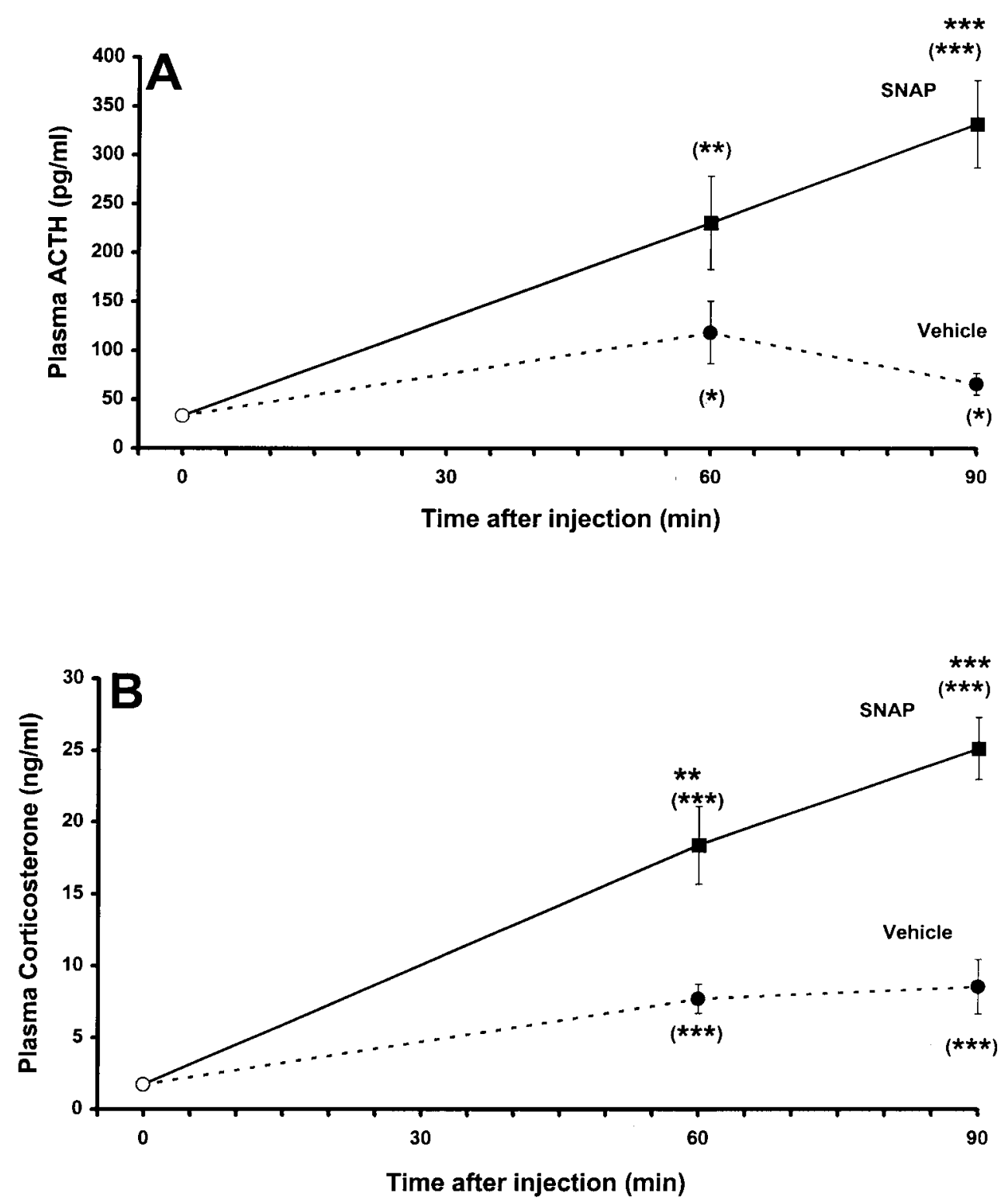

Figure 8 Plasma ACTH (A) and corticosterone (B) concentrations in 2-week-old newborn rats (W2) before (O) and after SNAP injection (5 mg/kg; SNAP group, $\mathbf{\square})$ or $0.9 \% \mathrm{NaCl}$ injection (vehicle group, ๑). Values are means \pm S.E.M. $(n=10-13)$. $\left(^{*}\right) P<0.05$, $\left.\left({ }^{\star \star}\right) P<0.01,{ }^{\star \star \star}\right) P<0.001$ vs time $0 \mathrm{~min} .{ }^{\star \star} P<0.01,{ }^{* \star \star} P<0.001$ SNAP vs vehicle group at the same time.

increase in the circulating concentration of ACTH and corticosterone $30 \mathrm{~min}$ later (Fig. 6); these were significantly larger than the increases observed 30 min after single injection of vehicle (Fig. 5). Nevertheless, morphine-induced activation of the pituitaryadrenal axis was prevented by pretreatment with NAL at a dose of $10 \mathrm{mg} / \mathrm{kg}$ (Fig. 6) but not at the dose of $0.4 \mathrm{mg} / \mathrm{kg}$ (data not shown). At a 90-min period, LNAME at $30 \mathrm{mg} / \mathrm{kg}$ had no significant effect on morphine-induced ACTH release and corticosterone release (data not shown). By contrast, a higher dose of
L-NAME $(100 \mathrm{mg} / \mathrm{kg})$ induced, by itself, a slight but significant increase in both plasma ACTH concentrations at 30 (Fig. 5A), 60 and 90 min after administration (Fig. 7A) and plasma corticosterone concentration at $60 \mathrm{~min}$ after injection (Fig. 7B). In newborns pretreated with the higher dose of L-NAME, and thereafter with morphine, circulating concentrations of ACTH (Fig. 7A) and corticosterone (Fig. 7B) were not significantly different from those observed in corresponding controls (pretreatment with L-NAME and thereafter with vehicle). SNAP injection at $5 \mathrm{mg} / \mathrm{kg}$ 
significantly increased ACTH release (Fig. 8A) as well as corticosterone release (Fig. 8B) at a 90-min period in 2-week-old pups.

\section{Discussion}

According to the present data, injections of vehicle solution produced a slight but significant release of ACTH and corticosterone in 2-week-old newborns but not in younger pups, indicating that, at this stage, injection per se could induce a stress response.

Such data are consistent with the existence of a 'stress hypo-responsive period' in early postnatal life $(21,22)$. In this study, we have shown that an acute administration of morphine was able to induce a drastic and long-lasting pituitary-adrenal stimulation in 2week-old newborns; by contrast, HPA axis activation was more transient and/or less robust in younger pups. ACTH and corticosterone release induced by morphine has been reported previously in 10-day-old rat pups (23). In agreement with our results, these authors reported that morphine-induced corticosterone release was lower on day 5 than on day 15 of postnatal life (23).

As NAL stimulated the HPA axis in pups, one can speculate that endogenous opioids may exert a tonic inhibition of this axis in newborns, as was reported in pregnant rats (24). In contrast, a stimulatory effect of endogenous opioids on the HPA axis response to physical stress has been reported in virgin rats (25).

On the other hand, NAL, when administered previously, also prevented morphine-induced stimulation of ACTH and corticosterone release in 2-week-old newborns. One can speculate that $\mu$-opiate receptors may be involved in the control of pituitary-adrenal function in early postnatal development; however, they showed controversial effects. This hypothesis is consistent with the development of $\mu$-receptors in the rat brain during the perinatal period (9) as well as of other opiate receptors including $\kappa$-receptors, which are detected in the brain of neonatal rats (11), and may be implicated in the control of the pituitary-adrenal axis within the first week of postnatal life (23). In adults, according to experiments performed in vivo and in vitro, the facilitation of ACTH secretion by morphine was correlated with the release of CRF $(15,26,27)$. However, a sparse opioid binding has been shown in the anterior pituitary gland (28) and opioids were not found to affect the release of ACTH from the pituitary in vivo (29). Moreover, we have previously reported that the hypothalamic content of CRF increases drastically in the developing rat from day 17 of gestation to week 4 post-partum (30), consistent with the hypothalamic control of the corticostimulating function of the pituitary gland as early as day 19 of gestation (3, 31). Thus, morphine-induced activation of hypophysial-adrenocortical activity in the neonate probably occurs via the release of CRF.
Controversial data with morphine ( $\mu$ - and $\kappa$-opioid receptor agonist) and NAL ( $\mu$-, $\kappa$ - and $\delta$-opioid receptor antagonist) suggest that, under our experimental conditions, the exogenous opiate (morphine) and the opioid peptides interacting with several types of opioid receptors affect the activity of the HPA axis differently in the developing brain.

Present data also suggest that, in neonates, morphine may act via the release of NO. This hypothesis is consistent with both the presence of neuronal NO synthase expression in the brain during embryonic development (32) and the prevention of morphine activation of the HPA axis by L-NAME, an NO synthase inhibitor (present data). The rise of circulating ACTH and corticosterone $30 \mathrm{~min}$ after vehicle injection in control pups previously treated with NAL or L-NAME illustrates the effects of two successive stressors. SNAP, an NO donor, also increased the release of ACTH and corticosterone in newborns and this mimics morphine's actions.

Our results are consistent with in vivo studies (33) showing that nitroprusside, an NO generator, induces CRF release. These results are also consistent with the work of Prevot et al. (15) indicating that, in vitro, morphine coupling to NO stimulates CRF release from adult rat median eminence fragments, as does the NO donor SNAP, and that morphine-induced CRF release was blocked by naloxone and L-NAME. In contrast, Costa et al. (34) reported that NO donors and precursors did not alter, in vitro, basal CRF release from the rat hypothalamus.

Because of our experimental conditions we cannot specify at what level of the neonatal brain the putative morphine-induced NO-mediated CRF release was occurring, and we cannot be precise about which is the origin of NO production (neuronal or endothelial source).

In conclusion, the present data suggest that both the endogenous opioid system and the NO one may be involved together in the modulation of the hypothalamo-pituitary adrenal axis in early postnatal development in rats.

In contrast, in 2-week-old newborns, plasma luteinizing hormone concentrations, which were higher in female pups than in male ones, were not significantly affected by several treatments which included morphine, NAL, L-NAME and SNAP at the previously reported doses and time-periods (authors' unpublished data). These data suggest that the gonadotropic axis matures differently from the corticotropic one during the first 2 weeks of postnatal life in rats.

\section{Acknowledgements}

The authors wish to thank Y Dodey for typing the manuscript and are very grateful to Dr Messines (Laboratoires Sanofi-Francopia) for the generous gift of morphine sulfate. This study was supported in part 
by grants from the Conseil Régional du Nord-Pas de Calais, Fonds de la Recherche et de la Technologie, Ministère de l'Education Nationale and Fonds Européens pour le Développement de la Recherche.

\section{References}

1 Martinez-Pinero M, Milanes V, Alcaraz M \& Vargas ML. Catecholaminergic mediation of morphine-induced activation of pituitary-adrenocortical axis in the rat: implication of $\alpha$ - and $\beta$ adrenoceptors. Brain Research 1994668 122-128.

2 Gilmore DP. The involvement of the endogenous opioids in the regulation of reproduction. Biogenic Amines 199814 331-354.

3 Dupouy JP \& Chatelain A. La fonction corticotrope dans la période périnatale. Journal de Physiologie (Paris) 198177 955968.

4 Lesage J, Bernet F, Montel V \& Dupouy JP. Effects of prenatal morphine on hypothalamic metabolism of neurotransmitters and gonadal and adrenal activities, during the early postnatal period in the rat. Neurochemical Research 199621 723-732.

5 Lesage J, Grino M, Bernet F, Dutriez-Casteloot I, Montel V \& Dupouy JP. Consequences of prenatal morphine exposure on the hypothalamo-pituitary adrenal axis in the newborn rat: effect of maternal adrenalectomy. Journal of Neuroendocrinology 199810 331-342.

6 Kirby M. Morphine in fetuses after maternal injection: increasing concentration with advancing gestational age. Proceedings of the Society for Experimental Biology and Medicine 1979162 287290.

7 Mansour A, Khatchaturian H, Lewis ME, Akill H \& Watson SJ. Anatomy of CNS opioid receptors. Trends in Neurosciences 1988 $11308-314$.

8 Kent J, Pert CB \& Herkenham M. Ontogeny of opiate receptors in rat forebrain: visualization by in vitro autoradiography. Developmental Brain Research 19822 487-504.

9 Watson SJJ, Neal CRJ, Thompson RC \& Vasquez DMV. Expression of the mu opioid receptor mRNA and protein in the developing rat brain. Society of Neurosciences Abstract 199723122.

10 Magnan J \& Tiberi M. Evidence for the presence of $\mu$ and $\kappa$ but not $\delta$-opioid sites in the human fetal brain. Developmental Brain Research 198945 275-281.

11 Kornblum HI, Hurlbut DE \& Leslie FM. Postnatal development of multiple opioid receptors in rat brain. Developmental Brain Research 198737 21-41.

12 Rius RA, Barg J, Bem WT, Coscia CJ \& Loh YP. The prenatal developmental profile of expression of opioid peptides and receptors in the mouse brain. Developmental Brain Research $199158237-243$.

13 Hammer RP. The sex hormone-dependent development of opiate receptors in the rat medial preoptic area. Brain Research 1985 360 65-74.

14 Becu-Villalobos D, Lacau-Mengido IM \& Libertun C. Ontogenic studies of the neural control of adenohypophyseal hormones in the rat: gonadotropins. Cellular and Molecular Neurobiology 1990 10 473-484.

15 Prevot V, Rialas CM, Croix D, Salzet M, Dupouy JP, Poulain P, Beauvillain JC \& Stefano GB. Morphine and anandamide coupling to nitric oxide stimulates GnRH and CRF release from rat median eminence: neurovascular regulation. Brain Research $1998790236-244$.

16 Torres G, Lee S \& River C. Ontogeny of the rat hypothalamic nitric oxide synthase and colocalization with neuropeptides. Molecular and Cellular Neuroscience 19934 155-163.

17 Nelson RJ, Kriegsfeld LJ, Dawson VL \& Dawson TM. Effects of nitric oxide on neuroendocrine function and behavior. Frontiers in Neuroendocrinology $1997 \mathbf{1 8} 463-491$.

18 Mansour A, Hoversten MT, Taylor LP, Watson SJ \& Akil H. The cloned $\mu, \delta$ and $\kappa$ receptors and their endogenous ligands: evidence for two opioid peptide recognition cores. Brain Research 1995700 89-98.

19 Deloof S, Montel V \& Chatelain A. Effects of rat corticotrophinreleasing factor, arginine vasopressin and oxytocin on the secretions of adrenocorticotrophic hormone and corticosterone in the fetal rat in late gestation: in vivo and in vitro studies. European Journal of Endocrinology 1994130 313-319.

20 Laborie C, Bernet F, Dutriez-Casteloot I, Lesage J \& Dupouy JP. Effect of cholinergic blockage on glucocorticoid regulation of NPY and catecholamines in the rat adrenal gland. Neuroendocrinology 199766 98-105.

21 Vazquez DM. Stress and the developing limbic-hypothalamicpituitary-adrenal axis. Psychoneuroendocrinology 199823 663700 .

22 Hary L, Dupouy JP \& Chatelain A. Pituitary response to bilateral adrenalectomy, metyrapone treatment and ether stress in the newborn rat. Biology of the Neonate 198139 28-36.

23 Adamson WT, Windh RT, Blackford S \& Kuhn CM. Ontogeny of $\mu$ - and к-opiate receptor control of the hypothalamo-pituitaryadrenal axis in rats. Endocrinology 1991 129 959-964.

24 Wigger A, Lorscher P, Oehler I, Keck ME, Naruo T \& Neumann ID. Nonresponsiveness of the rat hypothalamo-pituitary-adrenocortical axis to parturition-related events: inhibitory action of endogenous opioids. Endocrinology 1999140 2843-2849.

25 Douglas AJ, Johnstone HA, Wigger A, Landgraf R, Russel JA \& Neumann ID. The role of endogenous opioids in neurohypophysial and hypothalamo-pituitary-adrenal axis hormone secretory responses to stress in pregnant rats. Journal of Endocrinology 1998158 285-293.

26 Buckingham JC. Secretion of corticotropin and its hypothalamic releasing factor in response to morphine and opioid peptides. Neuroendocrinology $198235111-116$.

27 Nikolarakis KE, Pfeiffer A, Stalla G \& Herz A. The role of CRF in the release of ACTH by opiate agonists and antagonists in rats. Brain Research 1987421 373-376.

28 Simantow R \& Snyder SH. Opiate receptor binding in the pituitary gland. Brain Research $1977 \mathbf{1 2 4} 178-184$.

29 Pechnick RN, George R \& Poland RE. The effects of the systemic administration of $\mathrm{N}$-methylmorphine chloride, a quaternary analogue of morphine that does not cross the blood-brain barrier, on the release of anterior pituitary hormones in the rat. Psychoneuroendocrinology 198712 67-71.

30 Chatelain A, Boudouresque F, Chautard T, Dupouy JP \& Oliver C. Corticotrophin-releasing factor immunoreactivity in the hypothalamus of the rat during the perinatal period. Journal of Endocrinology $198811959-64$.

31 Chatelain A, Dubois MP \& Dupouy JP. Hypothalamus and cytodifferentiation of the fetal pituitary gland. Cell and Tissuse Research $1976169335-344$.

32 Santacana M, Uttenthal LO, Bentura ML, Fernandez AP, Serrano J, Martinez de Velasco J et al. Expression of neuronal nitric oxide synthase during embryonic development of the rat cerebral cortex. Developmental Brain Research $1998111205-$ 222.

33 Raber J, Koob GF \& Bloom FE. Interleukin-2 (IL-2) induces corticotrophin-releasing factor (CRF) release from the amygdala and involves a nitric oxide-mediated signaling; comparison with the hypothalamic response. Journal of Pharmacology and Experimental Therapeutics 1995272 815-824.

34 Costa A, Trainer P, Besser M \& Grossman A. Nitric oxide modulates the release of corticotropin-releasing hormone from the rat hypothalamus in vitro. Brain Research 19932 187-192.

Received 30 May 2000

Accepted 12 December 2000 